Sains Malaysiana 50(8)(2021): 2343-2354

http://doi.org/10.17576/jsm-2021-5008-17

\title{
Recovery of Latent Fingermarks on Metal Part of Motorcycle Submerged in Different Aquatic Environments
}

(Perolehan Semula Cap Jari Pendam pada Bahagian Logam Motorsikal Terendam di dalam Pelbagai Persekitaran Akuatik)

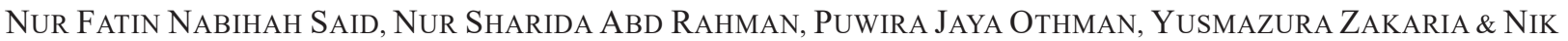 \\ FAKHURUDDIN NIK HASSAN
}

\begin{abstract}
Motorcycle theft cases in Malaysia have increased quite significantly with more motorcycles were reported stolen every day. In many cases, criminals had removed the components they only required and disposed the remaining parts into various sources of water. Unfortunately, the evidence recovered underwater was thought not to have forensic value with regards to fingermark recovery. This study aimed to determine the survivability of the latent fingermarks submerged in various water environments. Latent fingermarks were deposited on metal parts of motorcycle and submerged into four aquatic environments; river, lake, mine, and tap water for two weeks with time intervals for collection of 1, 8, 24, 48, 96, 168, and $336 \mathrm{~h}$. Upon recovery, the fingermark samples were developed using Small Particle Reagent (SPR). The developed fingermarks were assessed using Biometric Fingerprint Identification System (BIOFIS). The persistence of fingermarks immersed in tap water was found to last up to more than two weeks. Contrarily, fingermark in other water environments can only survive up to $96 \mathrm{~h}$ after being submerged. The fingermarks submerged in the lake appeared to be better preserved as compared to those submerged in the river and mine. The development of underwater fingermarks is still feasible, and identifiable fingermarks can still be recovered at the early submersion period.
\end{abstract}

Keywords: Aquatic environments; motorcycle; submerged fingermarks

ABSTRAK

Kes kecurian motosikal di Malaysia menunjukkan peningkatan yang sangat ketara dengan seratus kes kecurian dilaporkan setiap hari. Dalam kebanyakan kes, penjenayah akan mengeluarkan komponen motosikal yang diperlukan sahaja manakala bahagian yang tidak diperlukan akan dibuang ke dalam sungai, tasik, lombong dan juga pelbagai jenis sumber air yang lain. Malangnya, tiada percubaan untuk menimbulkan cap jari daripada bahagian motosikal yang dijumpai di dalam air kerana menyangka bahan bukti yang dijumpai di dalam air tidak mempunyai nilai forensik termasuklah dalam pencarian cap jari. Untuk menyangkal sangkaan tersebut, kajian ini dijalankan untuk mengenal pasti kemandirian cap jari pendam yang terendam di dalam pelbagai jenis persekitaran air dan kesannya pada penimbulan cap jari dengan menekankan persekitaran sebenar. Cap jari pendam diletakkan di atas kepingan logam daripada bahagian motosikal dan direndam di dalam empat jenis persekitaran air yang berbeza iaitu sungai, tasik, lombong dan air paip selama dua minggu dalam selang masa 1, 8, 24, 48, 96, 168 dan 336 jam. Dalam proses pengesanan cap jari, sampel dibiarkan kering di udara dan dibangunkan menggunakan Reagen Partikel Kecil (SPR). Kualiti cap jari yang telah diproses dinilai dan dibandingkan secara visual dengan menggunakan sistem Pengecaman Cap Jari Biometrik untuk menghasilkan laporan perbandingan cap jari. Selain itu, kekekalan cap jari yang direndam di dalam air paip didapati boleh bertahan sehingga tempoh dua minggu. Berbeza dengan cap jari yang direndam dalam air pada persekitaran semula jadi yang hanya mampu kekal sehingga jangka masa 96 jam sahaja selepas direndam. Cap jari yang direndam di dalam tasik menunjukkan ketahanan yang lebih baik berbanding dengan cap jari yang direndam di dalam sungai dan lombong. Secara kesimpulan, penimbulan cap jari yang terendam di dalam air masih boleh dijalankan dan pengenalpastian cap jari masih boleh dilaksanakan di peringkat awal tempoh rendaman.

Kata kunci: Cap jari terendam; motosikal; persekitaran akuatik 


\section{INTRODUCTION}

Property crime can be divided into several sections such as housebreaking, vehicle thefts, and snatch thefts (Sidhu 2005). Among these property crimes, vehicle thefts have contributed a significant number of cases. According to Vehicle Thief Reduction Council of Malaysia (VTREC) in 2019, motorcycle theft contributed the most reported cases compared to other types of vehicles with around 30,000 units were reported stolen annually between 2016 and 2018. Some of the missing motorcycles were recovered in many areas such as lake, river, drain, and water bank.

Criminals always try to commit a criminal offence and remain undetected to avoid responsibility for their illicit conduct (Trapecar 2012a). One of the ways in disposing of the evidence is by the means of waterways with the idea that items retrieved underwater will have no forensic significance (Devlin 2009). This poses a challenge to the crime scene investigators in investigating submerged evidence that has been subjected to destructive surrounding environments (Azman et al. 2018; Castelló et al. 2013). Investigators usually perceive evidence found in the water carry no forensic value, hence, no heavy effort was made on the methods of recovery such as the development of fingermark.

Most of the motorcycle frames and other parts recovered in the water from theft cases in Malaysia were of metal origin. Therefore, this study focuses on the development of submerged latent fingermarks on metal substrate emphasising on real case scenarios or cases encountered by the Royal Malaysia Police (RMP).

The fingermarks undergo certain modifications over time including ageing. Fingermark ageing is the result of various biological, physical, chemical, and environmental factors affecting the initial fingermark (Girod et al. 2012). Other factors have also been reported to influence the composition of the initial and aged fingermarks such as the donor characteristics, deposition, and environmental conditions, the enhancement techniques, and the nature of the substrate (Jasuja et al. 2008). Several studies were performed using laboratory environments to mimic field conditions, however, some studies carried out the experiments by submerging latent fingermarks on surfaces in field conditions. A study on the deterioration of latent fingermarks on a metallic substrate submerged in various depths of a natural aquatic environment was conducted in Ontario, Canada. The result showed that individualising power of the marks depends on the depth of the submergence in water (Yuille 2009).

In another study, the effects of current velocity and the period of submersion on the deterioration of friction ridge impression on the metallic blades after submersion in freshwater were investigated (Devlin 2009). The report showed that the mean mark visibility score was lower at the area with high current velocity compared to the area with low current. The mark visibility score is negatively correlated with the duration of submersion as latent fingermark residue deteriorated over time. Prolonged exposure to aquatic conditions attributed to the overall deterioration of friction ridge impressions. The impressions on the steel surface were almost completely obliterated after three days. The duration of the exposure to stagnant water and the methods selected for the enhancement was demonstrated to influence the quality of the recovered marks on glass and metal surfaces (Trapecar 2012a). Successful recovery of quality latent fingermarks from glass slide was also reported after seven days of submergence in river, sea, tap, or distilled water (Soltyszewski et al. 2007).

Some studies have been carried out to investigate the rate of degradation of submerged latent fingermarks in field and laboratory condition with further several development methods. The results demonstrated that marks submerged in field conditions survived longer than the laboratory conditions. Nevertheless, eccrine-rich latent fingermarks were unlikely to be recovered after extended periods of submersion (Sutton et al. 2014). Another study simulated underwater crimes to tackle the problem of developing marks that were deposited on submerged items (Castelló et al. 2013). The report suggested the possibilities to develop good quality latent fingermarks that were made underwater. A successful development of submerged latent fingerprint using Robin blue and silver magnetic powders on eight different non-porous surfaces was also reported in another study (Kapoor et al. 2019). Possible recovery of latent fingerprints submerged in fresh and seawater on non-porous surfaces and wet transparent foil has also been demonstrated (Madkour et al. 2017; Trapecar 2012b).

This study was performed to determine the persistency of fingermarks on the metal part of a motorcycle body after being submerged in various aquatic environment using techniques that are routinely employed by Crime Scene Investigation (CSI) Team, RMP at the crime scene 
or fingerprint laboratory namely black powder, black magnetic powder, cyanoacrylate(CA)/superglue, and Small Particle Reagent (SPR). Besides that, this study would also like to investigate the possibility of recovery and to visualise latent fingermarks when aged naturally in real uncontrolled conditions for specific periods.

The findings from this study are vital for the RMP in suggesting a time frame for successful recovery of latent fingermark from metal surfaces of a body part from a motorcycle after being disposed and submerged in the water under Malaysia climate. Law enforcement and authorities that are responsible for recovering the vehicle parts in the water for fingermark detection need to be cautioned in handling and processing the items.

\section{MATERIALS AND METHODS}

\section{EXPERIMENTAL DESIGNS}

The experiments were performed under four types of water environment namely river, lake, mine, and tap water to mimic the real environment in which most of the motorcycle parts were usually found. All samples in each experiment were analysed in triplicates.

Water samples from the river, lake, mine, and tap collected for the experiments were subjected to turbidity and $\mathrm{pH}$ determination. The turbidity of each sample was measured using 2100P Turbidim (Hach, USA) and $\mathrm{pH}$ was determined using $\mathrm{pH} 211$ Microprocessor $\mathrm{pH}$ M (Hanna, Portugal). The temperature of the waters was measured using Needle Tip Digital Thermom HT1 (Uxcell, UK) $\left(-50\right.$ to $\left.+300{ }^{\circ} \mathrm{C}\right)$ and HTC-1 LCD Thermom $\&$ Humidity M Digital was used to determine the humidity of the environment (Excites, UK). The water flow rate was determined using a float method described by Michaud and Wierenga (2005). This method requires the measurement and calculation of the cross-sectional area of the stream as well as the time it takes to 'float' a designated distance. A float was released into the stream from one point to another. The time taken for the 'float' to travel to the marked section was documented. The velocity was computed by dividing the length of the section (m) by the time (s) taken for the float to move through the section.

\section{DEPOSITION OF FINGERMARKS}

Prior to the experiment, the metal part from a body of a motorcycle (Honda, EX5) was cut into small pieces $(6 \times 4 \mathrm{~cm})$ that are able to accommodate the size of fingermarks (Figure 1(a) \& 1(b)). All metal plates were of the same type and in mint condition. The donor was instructed to wipe the fingers across the forehead and nose to obtain groomed fingermark prior to deposition. The metal plates were initially washed with acetone and distilled water, dried with cloth, and the fingermark was deposited by gently pressing the right thumb on the metals. The substrates bearing the fingermarks were then placed on a polystyrene board, tied inside the cage (Figure 1(c)) and submerged into the four types of the water environment.

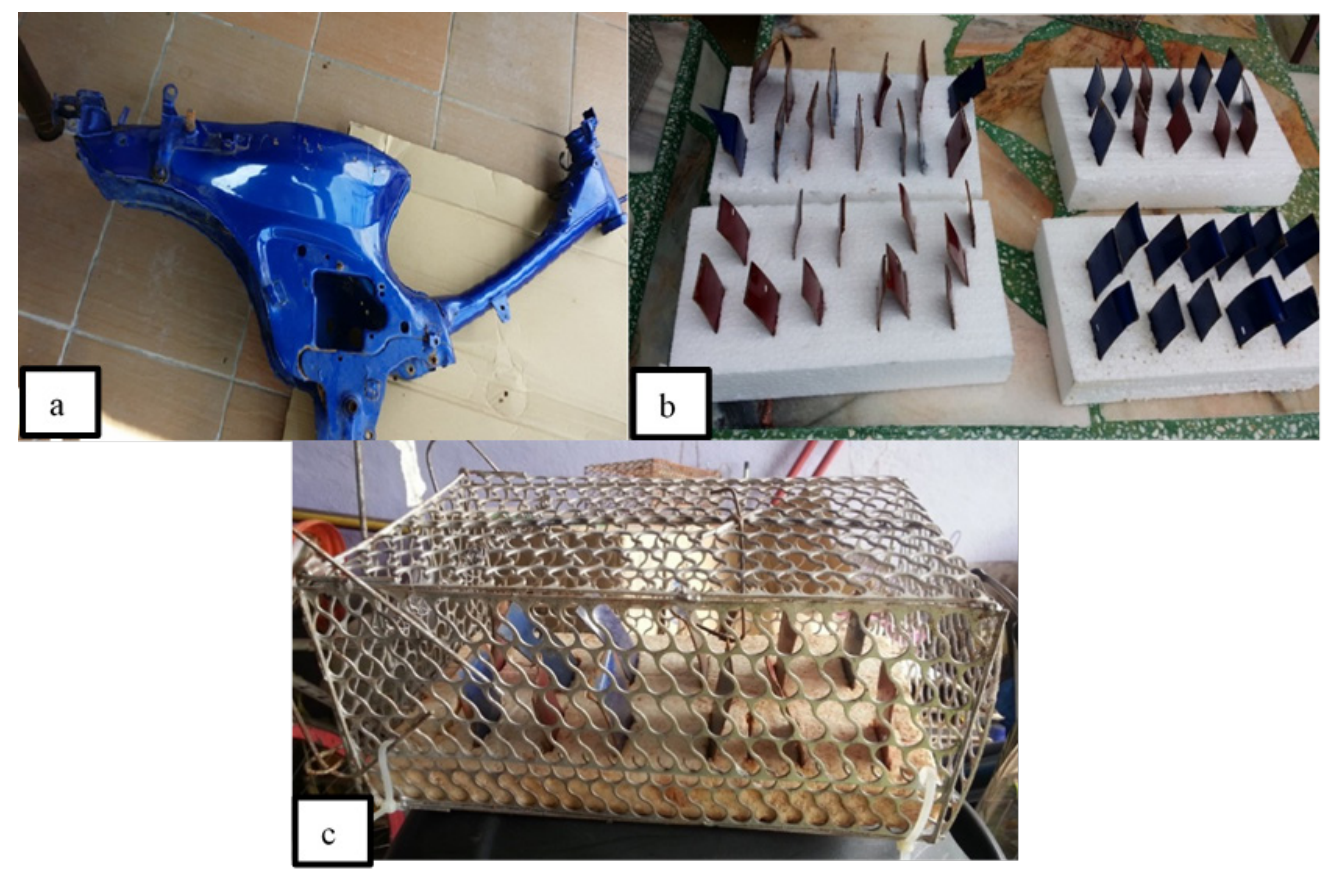

FIGURE 1. a) Motorcycle body's part was cut into small pieces of metal plates, b) Metal plates were placed on a polystyrene board, and c) Metal plates on a polystyrene board were tied in a cage 


\section{SUBMERGENCE IN THE WET ENVIRONMENT}

In a preliminary study, the development methods used for the submersion of fingermarks in tap water involve the routine methods namely powdering, SPR, and CA. Following fingermarks deposition, the metal plates bearing the fingermarks were submerged at $0.5 \mathrm{~m}$ in purified tap water for a total of $336 \mathrm{~h}$. All substrates were allowed to air-dry except for samples using the SPR method since this method was conducted in a wet condition after removal from the water environment. The main experiment was carried out at Sungai Ular, Timah Tasoh Lake, and Sungai Seluang mine (Figure 2(a) to 2(c)). Prior to the immersion into various water environments, a rod was measured to a depth of $0.5 \mathrm{~m}$. The depth of the submersion was constant throughout this study. The cage contained the metal plates bearing the fingermark was tied to the rod before being submerged into water. The cage was abandoned for specific time intervals and collected accordingly. The water temperature and the humidity of the environment were measured periodically. All water was sampled for $\mathrm{pH}$ and turbidity determination. Following fingermarks deposition, the metal plates bearing the fingermarks were submerged in each study location at $0.5 \mathrm{~m}$ depth for time intervals of $1,8,24,48,96,168$, and $336 \mathrm{~h}$. At the appropriate time intervals, the metal plates were removed, any adherence of mud and sediments on the surface of the metal plate were removed using water spray prior to the development of fingermarks. The cleaning process needs to be performed gently and carefully to avoid any disturbance on the fingermark ridge.

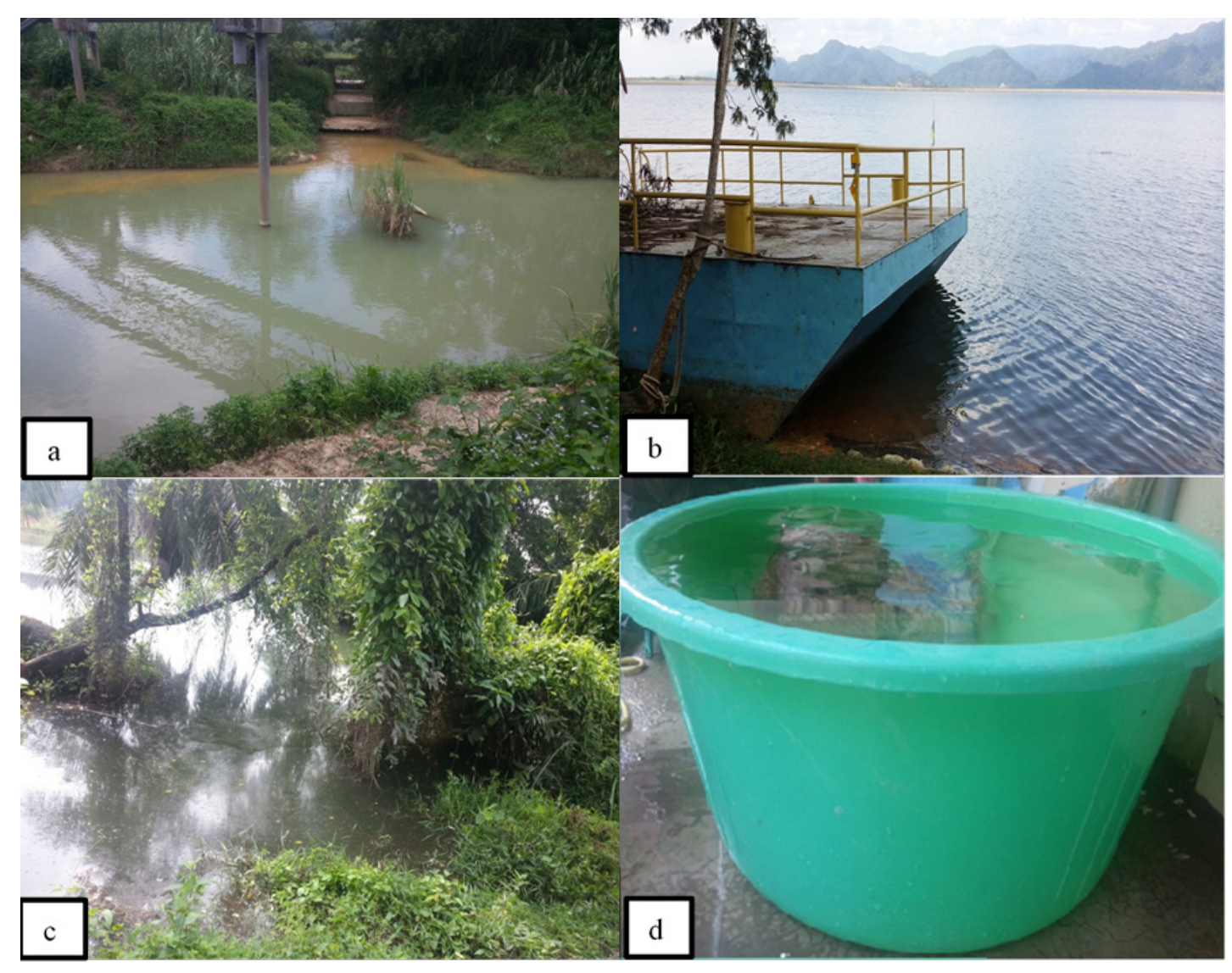

FIGURE 2. Study locations: a) river, b) lake, c) mine, and d) tap water 


\section{POWDERING WITH NON-MAGNETIC POWDER}

A heavy black 'SIRCHIE hi-fi valcano latent prints powder and black squirrel hairbrush were used as the main materials in this method and SIRCHIE latent fingerprint hinge lifting tape was used to preserve the developed fingermarks.

Prior to the application of powder formulation, the metal plate surfaces were completely dried to avoid depositing smeared marks. A light powdering was applied and slowly a heavier application was performed to minimise damage to the fingermarks. The excess powder was shaken, spun or tapped from the brush before evenly applied to all areas of the substrates.

In this study, fingerprint hinge lifting tape was used where the adhesive square was attached to the backing card using a hinge, which is on opaque adhesive gel lifter. In the process of lifting, the tape was rubbed to remove air bubbles and to ensure good adhesion to the latent fingermarks. The developed fingermarks were then photographed.

\section{POWDERING WITH MAGNETIC POWDER}

In this method, a silver/black latent print powder and magnetic 'mega wand magnetic powder applicator' (SIRCHIE) were used as the main materials. The magnetised applicator (magna brush) was first dipped into the powder, picking up a ball of iron and particle mixture, essentially forming a brush that serves as an effective carrier for the pigment particle. It was then passed back and forth over the metal plate bearing the fingermarks to develop latent impressions.

\section{CYANOACRYLATE (CA)/SUPERGLUE FUMING FOLLOWED BY NON-MAGNETIC POWDERING}

A commercially prepared cyanoacrylate fuming kit (SIRCHIE), namely Cyano-Shot was employed in this method. Prior to superglue fuming, metal plates bearing latent fingermarks were arranged vertically inside the chamber in order to achieve maximum exposure to the superglue fume. Then, the superglue fuming kit was placed in the fuming chamber with reference to the published technical procedure for cyanoacrylate ester development kits. Cyano-Shot activator solution was placed in the middle of the chamber followed by the addition of activator crystals canister, which was then left to soak into the solution. The superglue fuming compound was placed in a bowl mounted above the activator canister.
The fuming cabinet was closed to ensure that the vapour remained inside the chamber. Before closing the chamber, a fingermark sample was deposited onto the glass door of the fuming cabinet as a benchmark. When the benchmark's fingermark appeared to be visible as white colour polymer, this is an indication that the same changes happened to the tested metal plates. The fuming process was allowed to run for $15 \mathrm{~min}$.

The visibility of the fingermarks on the metal was improved by further enhancement technique using nonmagnetic powder. All metal plates were left for $2 \mathrm{~h}$ prior to further enhancement to make sure that the superglue adhered well on the surface of the sample. The developed fingermarks were tape lifted and photographed.

\section{SMALL PARTICLE REAGENT (SPR)}

A commercially available black SPR, (SIRCHIE) was used in this method. All submerged metal plates bearing the latent fingermarks were directly treated with SPR using a spraying technique. Metal plates were then left for $2 \mathrm{~min}$ prior to the cleaning process with slow-flowing water. The process was repeated until the fingermarks appeared on the metal plates. The developed fingermarks were then left to air-dry at an ambient temperature before lifting process. Each developed fingermark was assessed using a scoring system. The developed fingermarks were tape lifted and photographed.

\section{ASSESSMENT OF DEVELOPED FINGERMARKS}

The developed fingermarks were submitted to Central Criminal Registry (CCR), Bukit Aman, Kuala Lumpur for comparison using BIOFIS by fingerprint expert to determine the characteristics for identification. A match of 12 min points between the developed fingerprints and reference fingerprints was considered as positive identification. The use of BIOFIS and verification by fingerprint specialist in this study is to make sure that the developed fingermarks from the whole experiments were assessed in an objective manner. This is also to enhance the value of this study as the admissibility of the fingerprint evidence to the court is mostly dependent on the BIOFIS identification and report by the fingerprint specialist.

The visibility and quality of the ridge detail or minutiae of the developed fingermarks in this study were assessed using a holistic scale developed by the Centre for Applied Science and Technology as outlined in Table 1 (Almog et al. 2014). The grading system was used to 
score the quality of the ridge or minutiae on the developed fingerprints following each development method. IBM SPSS version 20.0 software was utilised for statistical analysis. Kruskal-Wallis test was used to compare the differences in medians with regard to the quality of fingerprints developed from each aquatic environment. $P$-value of less than $0.05(P<0.05)$ was considered statistically significant.

TABLE 1. Description of the scale used to score the developed fingermarks quality

\begin{tabular}{ll}
\hline Grade & Detail visualized \\
\hline 0 & No evidence of a fingermark \\
1 & Some evidence of a fingermark \\
2 & Less than $1 / 3$ clear ridge detail \\
3 & Between $1 / 3$ and $2 / 3$ clear ridge detail \\
4 & Over $2 / 3$ clear ridge detail \\
\hline
\end{tabular}

\section{RESULTS AND DiscUSSION}

\section{PRELIMINARY STUDY-RECOVERY OF LATENT \\ FINGERMARKS SUBMERGED IN TAP WATER}

The deposition time and the application of suitable development methods play a critical role in developing the fingermarks. Fresh fingermarks have a good chance of being detected whereas aged fingermarks will suffer from degradation, dehydration, loss of stickiness, and prone to bacterial attack (Lennard 2011). Figure 3 demonstrates a good clarity of latent fingermark was developed using SPR at submersion time intervals up to $336 \mathrm{~h}$ as compared to other routine development methods. This suggests that the quality of the developed fingermarks is dependent on the method applied. The development method affected the recovery even though the fingermarks were submerged for the same period in the same type of water. Table 2 shows the overall visibility score of the fingermarks after being submerged in tap water at different time intervals for each development method. Statistically, the KruskalWallis test results indicated that there was no significant difference in the quality of all developed fingermarks. Nevertheless, it was evident that SPR method exhibited good clarity fingermarks at longer submersion time as noted by the fingerprint expert. Hence, this method was chosen for the main study.

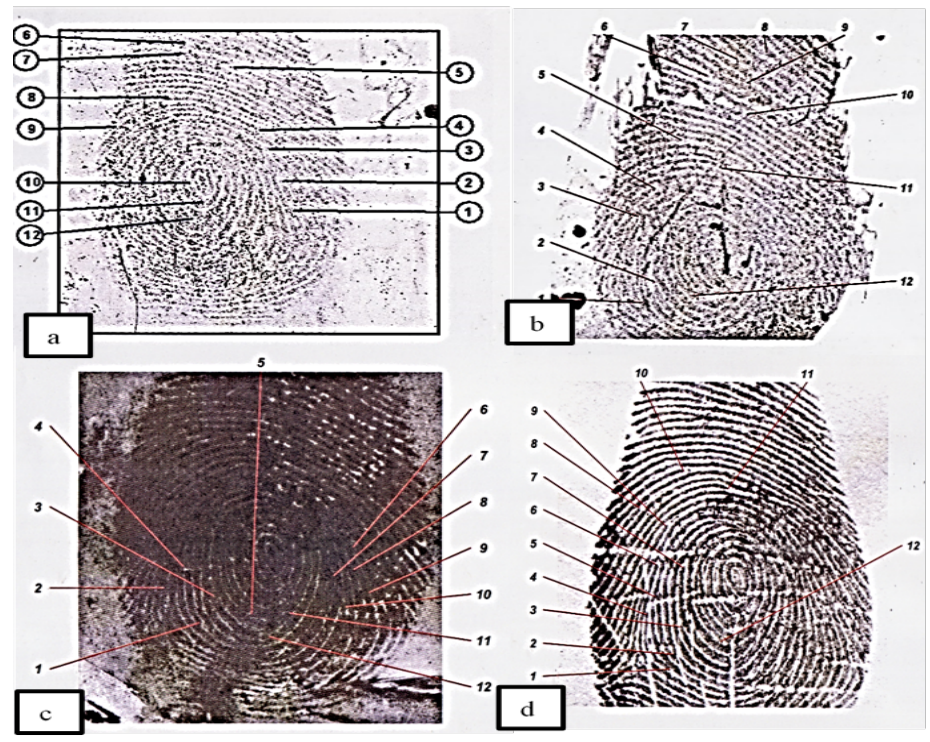

FIGURE 3. BIOFIS analysis of the developed fingermarks submerged in tap water for $336 \mathrm{~h}$ a) using non-magnetic powder, b) magnetic powder, c) CA followed by non-magnetic powder, and d) SPR 
TABLE 2. Overall visibility score of ridges lines of fingermarks submerged in tap water at different time intervals

\begin{tabular}{ccccc}
\hline & \multicolumn{4}{c}{ Visibility Score } \\
\cline { 2 - 5 } Time intervals (h) & $\begin{array}{c}\text { Non-magnetic } \\
\text { powder }\end{array}$ & Magnetic powder & $\begin{array}{c}\text { CA followed by non- } \\
\text { magnetic powder }\end{array}$ & SPR \\
\hline 1 & 4 & 4 & 4 & 4 \\
8 & 4 & 4 & 4 & 4 \\
24 & 4 & 4 & 4 & 4 \\
48 & 4 & 3 & 4 & 4 \\
96 & 4 & 3 & 4 & 4 \\
336 & 3 & 2 & 3 & 4 \\
\hline
\end{tabular}

\section{PARAMETERS OF THE AQUATIC ENVIRONMENTS}

Deterioration and degradation of fingermark's impression and the effectiveness of some development techniques are affected by many factors such as the type of surfaces, temperature, and humidity of the environment, weather conditions, and the type of the submersion water (Baniuk 1990). In this study, various types of water environment were tested that have different characteristics in terms of $\mathrm{pH}$, salt types and levels, turbidity, temperature, impurities, and sediment. The parameter variations in each aquatic environment may influence the degradation of latent fingermarks that resulted in different clarity of the visualised fingermarks. The $\mathrm{pH}$ of the river, lake, and tap water were $6.38,6.84$, and 6.08 , respectively. The $\mathrm{pH}$ was all in the range of weak acidic condition whereas $\mathrm{pH}$ for mine water was recorded as neutral. All developed fingermarks recovered from river, lake, and mine showed a good quality of friction ridges but for a limited time of submersion intervals. Regardless of $\mathrm{pH}$, friction ridges impressions on metal surfaces were completely obliterated at a longer submersion. Although the $\mathrm{pH}$ of the tap water was more acidic compared to lake and river, the developed fingermark showed a very good clarity on friction ridge impression even after two weeks using black powder, CA, and SPR. The results showed that $\mathrm{pH}$ is just an additive factor playing a small role in the quality of the recovered fingermarks. Small differences in the range of $\mathrm{pH}$ have no effect on the persistence of latent fingermark and the quality of the developed fingermarks. The findings in this study are in agreement with previous study that reported soaking solvent such as tap water and another medium of weak acid and base did not affect the effectiveness of SPR for the development of fingermarks (Kabklang et al. 2009).

Turbidity is the cloudiness or haziness of a fluid caused by suspended particles that are usually invisible by the naked eye. The particles can be from silt, mud, clay and sand, bacteria and other gems, chemical precipitates, and might also come from the wastewater discharges. In this experiment, the turbidity recorded for the lake, river, and tap water were $1.19,1.71$, and 1.04 NTU, respectively. The highest water turbidity was recorded from mine with 323.00 NTU. Although mine water recorded very high cloudiness and murkiness, fingermark recovered from mine water showed a very clear friction ridge when developed compared to river and lake. This indicates that other external factors may also affect the survivability of the developed fingermarks such as the presence of sediments and the growth of macrophytes (aquatic plants) at the bottom of the river sand. The sediments were found to be mud-like deposits, which adhered to the metal plates that masked the area bearing the latent fingermarks. The 
adherence of sediment on the metal surface may be one of the features that tended to have the most negative effect on the ability to enhance a fingermark. The turbid water affected the result with the presence of suspended particles including contaminations and organic and inorganic materials from the environment (Rahmanian et al. 2015). It has been shown that suspended particles on metal plates resulted in poor minutiae recovery after being developed using all development methods. The outdoor aquatic environments were also vulnerable to variation in the microbial community hence, variations in turbidity were expected.

In addition, a rainstorm of varying degrees that occurred during the submersion experiment in the river elevated the streams water level and more particles suspended to the experiment area resulted in degraded latent fingermark. The stream velocity was at its greatest midstream near the surface and at slowest along the stream banks due to the friction caused by the sediment (Wetzel 2001). The flow rates for river, lake, and mine were $0.083,0.058$, and $0.050 \mathrm{~m} / \mathrm{s}$, respectively. The velocity of the water changes with the depth of the water. In this study, the depth of the submergence was standardised at $0.5 \mathrm{~m}$, however, the stream velocity may be affected by rainfall and drainage from the neighbouring areas since the stream is located in a developed watershed. Hence, the velocity of the water for all tested environments may slightly change throughout this study.

Fingermarks recovered from metal plates submerged in stagnant tap water showed good visibility with detailed ridge characteristics when developed using all development methods. In contrast, poor quality of developed fingermarks was prevalent in marks recovered from the river. This could be due to the velocity of the stream which was affected by the rainfall during the submersion experiment. The increase of wave interaction were observed and proven to have a significant impact on the print visible score. The marks recovered were almost completely smudged or obscured. The flow rates of lake and mine were almost similar hence the latent fingermarks recovered from these water environments shown to survive longer than the river.

In this study, water temperatures, air, and humidity of the air were recorded. For the river, the water average and air temperatures were 25.5 and $26.6{ }^{\circ} \mathrm{C}$, respectively, and humidity was $62 \%$. The average air and water temperatures for the lake were 27.4 and $23.8^{\circ} \mathrm{C}$, respectively while the humidity was $72 \%$. For mine, the average air and water temperatures were 29.5 and $21.0^{\circ} \mathrm{C}$ while the humidity was $71 \%$. For the tap water, the average water and air temperatures were 29.3 and $26.6{ }^{\circ} \mathrm{C}$ with $37 \%$ humidity. The temperatures were all concurrent with typical Malaysian ambient temperature.

\section{RECOVERY OF LATENT FINGERMARKS SUBMERGED IN RIVER}

Good clarity of fingermarks was developed from metal plates submerged in the river within $96 \mathrm{~h}$ of submersion period. A faint fingermark can only be developed from metal plates submerged at a longer period with no ridge details for further comparison (Figure 4). It is visible to locate the deposited fingermark area. The BIOFIS results indicated that SPR managed to recover fingermarks with 4 min points match after $96 \mathrm{~h}$ of submersion. Loss of water-soluble compounds and lipids could be attributed to the poor recovery of ridge detail at a longer submersion period. SPR has demonstrated its effectiveness in developing fingermarks from the river after being submerged for a longer period. The high-water flow rate during raining has been thought to affect the quality of the recovered fingermarks.

The results clearly indicate that the river condition plays a role to affect the persistence of the latent fingermarks. The atmospheric conditions such as temperature, humidity, air pollution, and rainfall were the contributory factors (Baniuk 1990). The correlation between the survivability of the fingermarks with the changeable atmospheric condition is more easily observed when these conditions become extreme. This was seen in this study as the submerged metal parts were exposed to an extreme stream current during a rainstorm for several days. This caused an extra wave interaction and sediments deposition on the substrates.

\section{RECOVERY OF LATENT FINGERMARKS SUBMERGED IN LAKE}

SPR developed good clarity fingermarks within $48 \mathrm{~h}$ of submersion period. As the time of submersion increased, the clarity of the ridge decreased and only traces of fingermarks can be recovered, which are insufficient for comparison purposes (Figure 5). This method is effective in developing identifiable fingermarks with clear ridge detail but only within $48 \mathrm{~h}$ of submersion period as 

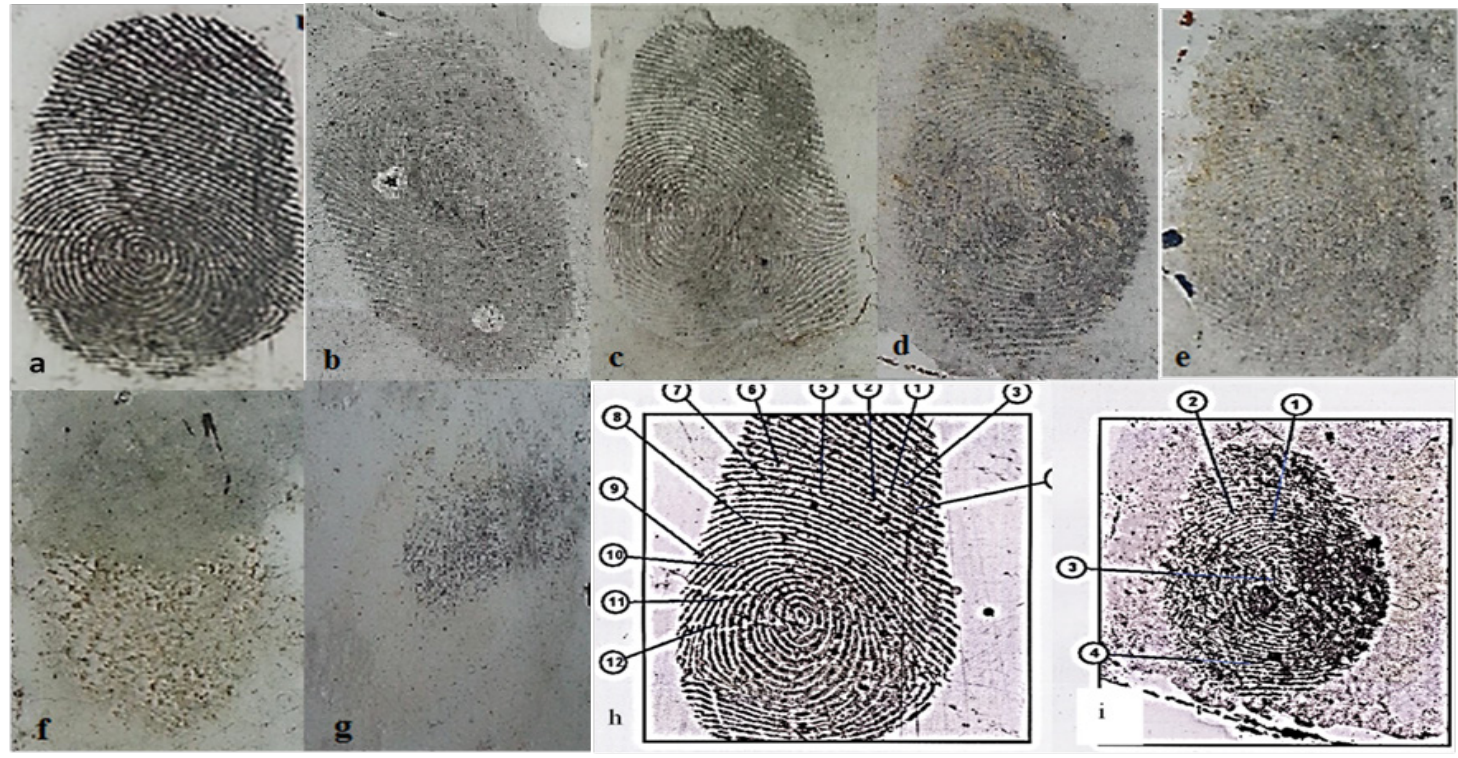

FIGURE 4. Developed fingermarks in the river after a) $1 \mathrm{~h}$, b) $8 \mathrm{~h}, \mathrm{c}) 24 \mathrm{~h}$,

d) $48 \mathrm{~h}$, e) $96 \mathrm{~h}, \mathrm{f}) 168 \mathrm{~h}$, and g) $336 \mathrm{~h}$ of submersion and BIOFIS analysis developed fingermarks submerged in the river for h) $1 \mathrm{~h}$ and i) $96 \mathrm{~h}$

depicted by BIOFIS analysis. After $48 \mathrm{~h}$, no ridge detail was obtainable. As the submersion time increased, poor quality images of fingermarks were developed using SPR.
In general, fingermark visibility scores are negatively related to the duration of submersion. This is expected due to the deterioration of fingermark residues over time.

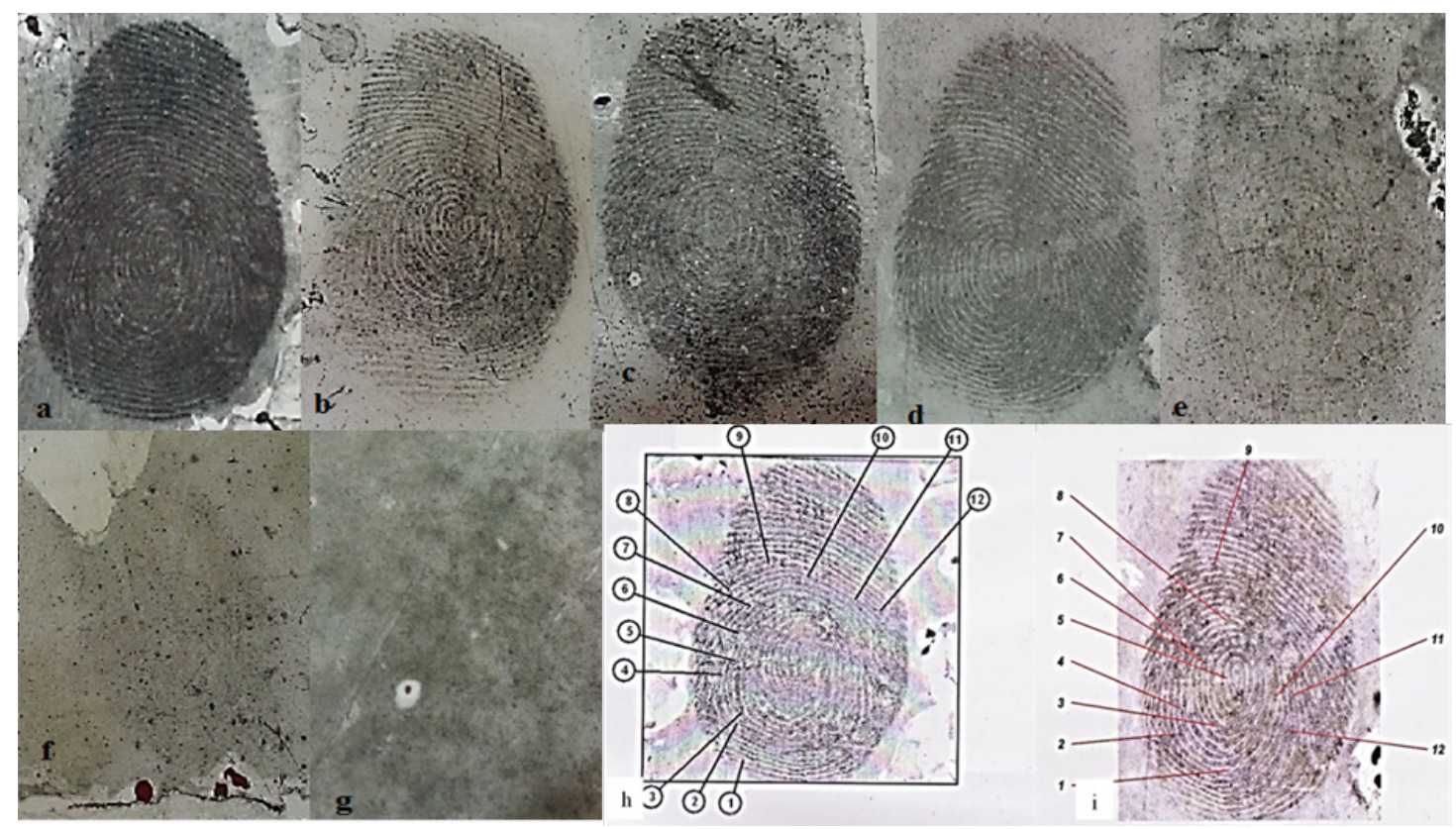

FIGURE 5. Developed fingermark in the lake after a) $1 \mathrm{~h}$, b) $8 \mathrm{~h}$, c) $24 \mathrm{~h}$, d) $48 \mathrm{~h}$, e) $96 \mathrm{~h}$, f) $168 \mathrm{~h}$, and g) $336 \mathrm{~h}$ of submersion and BIOFIS analysis of developed fingermarks submerged in the lake for h) $1 \mathrm{~h}$ and i) $48 \mathrm{~h}$ 


\section{RECOVERY OF LATENT FINGERMARKS SUBMERGED IN MINE}

The developed fingermarks with identifiable details and pattern were obtainable until $48 \mathrm{~h}$ of submersion in the mine. The visibility of the fingermark ridges deteriorated after $96 \mathrm{~h}$ of submersion period (Figure 6). A match of twelve minutiae points using BIOFIS analysis was obtained from the developed fingermarks within $48 \mathrm{~h}$ of submersion period. However, poor recovery of minutiae points for comparison limiting the positive identification for the developed fingermarks submerged in mine after 48 h. Nevertheless, results from this study demonstrated that even under unfavourable condition, latent fingermarks survived for a longer period.

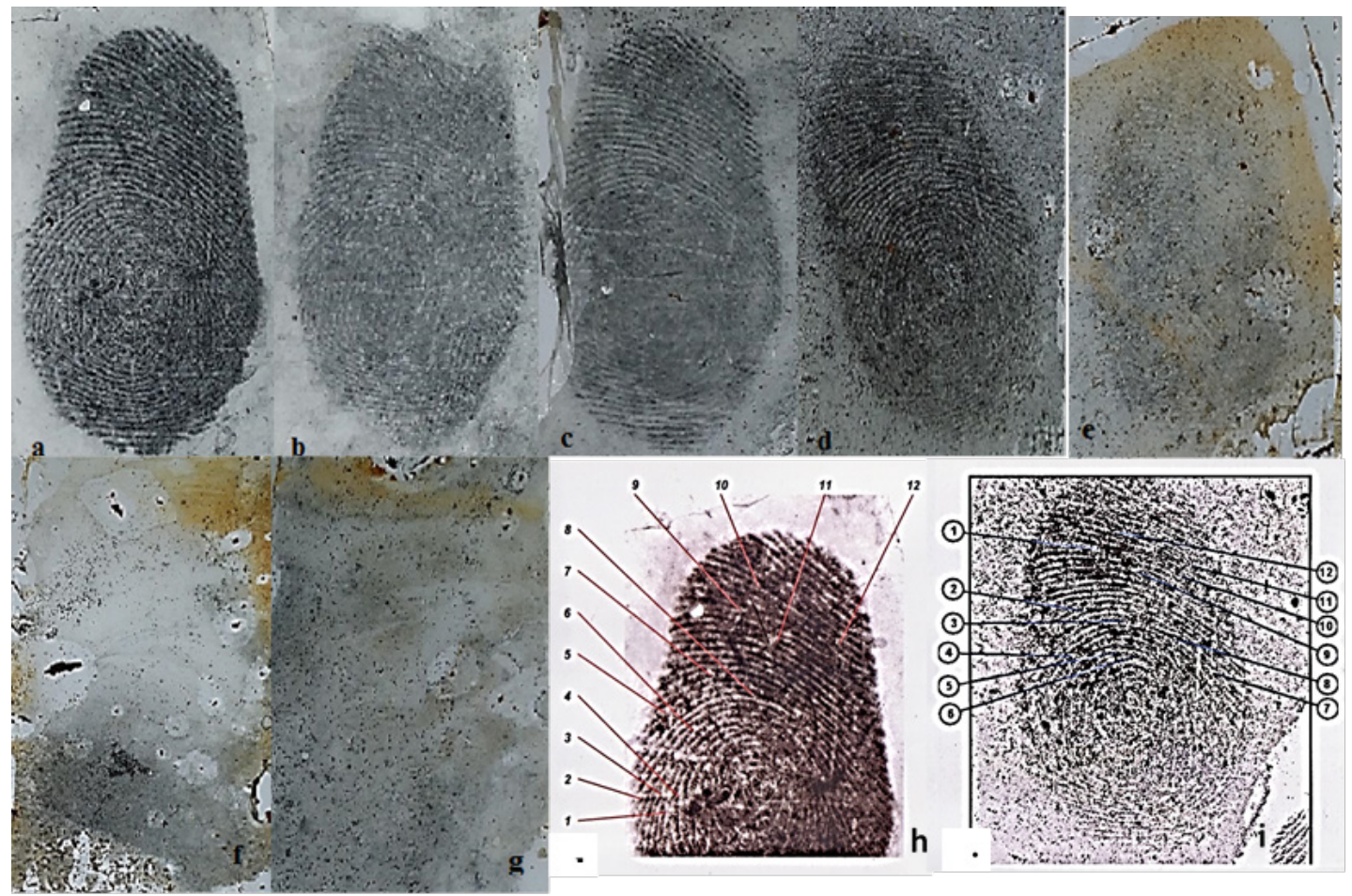

FIGURE 6. Developed fingermark in mine after a) $1 \mathrm{~h}$, b) $8 \mathrm{~h}, \mathrm{c}$ ) $24 \mathrm{~h}, \mathrm{~d}$ ) $48 \mathrm{~h}$, e) $96 \mathrm{~h}, \mathrm{f}) 168 \mathrm{~h}$, and g) $336 \mathrm{~h}$ of submersion and BIOFIS analysis of developed fingermarks submerged in mine for h) $1 \mathrm{~h}$ and i) $48 \mathrm{~h}$

Although a number of factors may affect the survivability of the latent fingermarks such as submersion period, environmental conditions also exert significant effects. The fingermark residues deteriorated when exposed to surrounding environments. This is apparent as wide variations exist in the ability of the latent fingermark to survive in a different type of water environments. The other factors in natural aquatic environments that could affect the persistence of latent fingermarks include water flow rate, turbidity, and the presence of sediment. Microflora could have established and may have degraded the sebumcontaining materials on the submerged metal plates and 
environmental challenges such as currents could have eroded the latent fingermarks from the plates resulted in poor development. The metal could undergo oxidisation in the water when submerged at a longer period. The $\mathrm{pH}$ and temperatures of the water and surrounding environments were within similar range for all water types. Therefore, no significant variations were observed in the quality of the recovered fingermarks. Table 3 shows the overall visibility score of the fingermarks developed using SPR after being submerged in various aquatic environments at different time intervals. Furthermore, the Kruskal-Wallis test results also indicated that there was no significant difference in the quality of all SPR developed fingermarks.

TABLE 3. Overall visibility score of ridges lines of fingermarks developed using SPR after being submerged in various aquatic environments at different time intervals

\begin{tabular}{ccccc}
\hline \multirow{2}{*}{ Time intervals (h) } & \multicolumn{5}{c}{ Visibility Score } \\
\cline { 2 - 5 } & Tap & River & Lake & Mine \\
\hline 1 & 4 & 4 & 4 & 4 \\
8 & 4 & 3 & 4 & 4 \\
24 & 4 & 3 & 4 & 4 \\
48 & 4 & 2 & 4 & 3 \\
96 & 4 & 2 & 2 & 2 \\
168 & 4 & 1 & 1 & 1 \\
336 & 4 & 1 & 1 & 1 \\
\hline
\end{tabular}

\section{CONCLUSION}

This study has established and confirmed that the latent fingermarks on a metal surface can survive for a long time after submersion in water however, a suitable technique must be used to develop good quality fingermarks. SPR was found to establish the highest visibility score of developed fingermarks for identification. Poor recovery of identifiable ridge detail in the developed fingermarks was observed when submerged at longer period has been a predicament for positive identification. Natural environmental factors such as water flow rate especially during raining, turbidity, and the presence of sediment have a huge impact on the successful recovery of the fingermarks with good clarity. The results from this study prove that items of forensic relevance from motorcycle part submerged in water should not be discounted. Fingermark development should be attempted even if it is recovered after two weeks in underwater. These items could hold valuable latent fingerprint evidence that may serve as an identification of the perpetrator.

\section{ACKNOWLEDGEMENTS}

The authors acknowledge the supports from Universiti Sains Malaysia (USM) Research University Grant: 1001/ PPSK/812125. 


\section{REFERENCES}

Almog, J., Cantu, A.A., Champod, C., Kent, T. \& Lennard, C. 2014. Guidelines for the assessment of fingermark detection techniques international fingerprint research group. Journal of Forensic Identification 64(2): 174-200.

Azman, A.R., Mahat, N.A., Abdul Wahab, R., Abdul Razak, F.I. \& Hamzah, H.H. 2018. Novel safranin-tinted Candida rugosa lipase nanoconjugates reagent for visualizing latent fingerprints on stainless steel knives immersed in a natural outdoor pond. International Journal of Molecular Sciences 19(6): 1576.

Baniuk, K. 1990. Determination of age of fingerprints. Forensic Science International 46(1-2): 133-137.

Castelló, A., Francés, F. \& Verdú, F. 2013. Solving underwater crimes: Development of latent prints made on submerged objects. Science \& Justice 53(3): 328-331.

Devlin, B.E. 2009. Recovery of latent fingerprints after immersion in various aquatic conditions. George Mason University. MS Thesis (Unpublished).

Girod, A., Ramotowski, R. \& Weyermann, C. 2012. Composition of fingermark residue: A qualitative and quantitative review. Forensic Science International 223(1-3): 10-24.

Jasuja, O.P., Singh, G.D. \& Sodhi, G.S. 2008. Small particle reagents: Development of fluorescent variants. Science \& Justice 48(3): 141-145.

Kabklang, P., Riengrojpitak, S. \& Suwansamrith, W. 2009. Latent fingerprint detection by various formulae of SPR. Journal of Scientific Research, Chulalongkorn University 34(2): 59-64.

Kanyo, N.I., Nor, N.H.M., Rainis, R., Rahman, A.T.R. \& Jubit, N. 2015. Crime and Malaysia's development agenda: An overview. Malaysian Journal of Society and Space 11(1): 124-134.

Kapoor, N., Ahmed, S., Shukla, R.K. \& Badiye, A. 2019. Development of submerged and successive latent fingerprints: A comparative study. Egyptian Journal of Forensic Sciences 9: 44.

Lennard, C. 2013. Fingerprint detection and identification: Current research efforts. Australian Journal of Forensic Sciences 46(3): 293-303.

Michaud, J.P. \& Wierenga, M. 2005. Estimating Discharges and Stream Flows: A Guide for Sand and Gravel Operators. Washington: Ecology Publication. p. 70.
Madkour, S., Sheta, A., Badr El Dine, F., Elwakeel, Y. \& AbdAllah, N. 2017. Development of latent fingerprints on non-porous surfaces recovered from fresh and sea water. Egyptian Journal of Forensic Sciences 7(1): 3.

Rahmanian, N., Siti Hajar Bt Ali, Homayoonfard, M., Ali, N.J., Rehan, M., Sadef, Y. \& Nizami, A.S. 2015. Analysis of physiochemical parameters to evaluate the drinking water quality in the state of Perak. Journal of Chemistry 2015: 716125.

Sidhu, A.S. 2005. The rise of crime in Malaysia. Journal of the Kuala Lumpur Royal Malaysia College 4: 1-28.

Soltyszewski, I., Moszczynski, J., Pepinski, W., Jastrzebowska, S., Makulec, W., Zbiec, R. \& Janica J. 2007. Fingerprint detection and DNA typing on objects recovered from water. Journal of Forensic Identification 57(5): 681-687.

Sutton, R., Grenci, C. \& Hrubesova, L. 2014. A comparison on the longevity of submerged marks in field and laboratory conditions. Journal of Forensic Identification 64(2): 143156.

Trapecar, M. 2012a. Finger marks on glass and metal surfaces recovered from stagnant water. Egyptian Journal of Forensic Sciences 2(2): 48-53.

Trapecar, M. 2012b. Fingerprint recovery from wet transparent foil. Egyptian Journal of Forensic Sciences 2(4): 126-130.

Wetzel, R.G. 2001. Limnology: Lake and River Ecosystems. San Diego, California: Gulf Professional Publishing.

Yuille, M.J. 2009. Deterioration of friction ridge impressions on a metallic substrate after submergence in lake water. Identification Canada 32(2): 48-62.

Forensic Science Programme

School of Health Sciences

Universiti Sains Malaysia

Health Campus, Kubang Kerian

16150 Kota Bharu, Kelantan Darul Naim

Malaysia

*Corresponding author; email: nikf@usm.my

Received: 10 August 2020

Accepted: 9 December 2020 